\title{
Development of a qPCR Method for the Identification and Quantification of Two Closely Related Tuna Species, Bigeye Tuna (Thunnus obesus) and Yellowfin Tuna (Thunnus albacares), in Canned Tuna
}

\author{
Bojolly Daline ${ }^{1,6,8}$, Doyen Périne ${ }^{1,2,3,4,5}$, Le Fur Bruno ${ }^{8}$, Christaki Urania ${ }^{6}$, \\ Verrez-Bagnis Veronique ${ }^{7}$, Grard Thierry ${ }^{1,2,3,4,5,{ }^{*}}$
}

${ }^{1}$ Université Littoral Côte d'Opale, EA 7394 - ICV - Institut Charles Viollette, USC Anses - ULCO, F62200 Boulogne-sur-Mer, France

${ }^{2}$ Université Lille, F-59000 Lille, France

${ }^{3}$ Université Artois, F-62000 Arras, France

${ }^{4}$ INRA, France

${ }^{5}$ ISA, F-59000 Lille, France

${ }^{6}$ Laboratoire d'Océanologie et de Géosciences, UMR 8187 (ULCO, Lille 1, CNRS), 62930 Wimereux, France

${ }^{7}$ Ifremer, F-44300 Nantes, France

${ }^{8}$ PFINV, F-62200 Boulogne-sur-Mer, France

* Corresponding author : Thierry Grard, email address : thierry.grard@univ-littoral.fr

\begin{abstract}
:
Bigeye tuna (Thunnus obesus) and yellowfin tuna (Thunnus albacares) are among the most widely used tuna species for canning purposes. Not only substitution but also mixing of tuna species is prohibited by the European regulation for canned tuna products. However, as juveniles of bigeye and yellowfin tunas are very difficult to distinguish, unintentional substitutions may occur during the canning process. In this study, two mitochondrial markers from NADH dehydrogenase subunit 2 and cytochrome c oxidase subunit II genes were used to identify bigeye tuna and yellowfin tuna, respectively, utilizing TaqMan qPCR methodology. Two different qPCR-based methods were developed to quantify the percentage of flesh of each species used for can processing. The first one was based on absolute quantification using standard curves realized with these two markers; the second one was founded on relative quantification with the universal 12S rRNA gene as the endogenous gene. On the basis of our results, we conclude that our methodology could be applied to authenticate these two closely related tuna species when used in a binary mix in tuna cans.
\end{abstract}




\section{Graphical abstract}

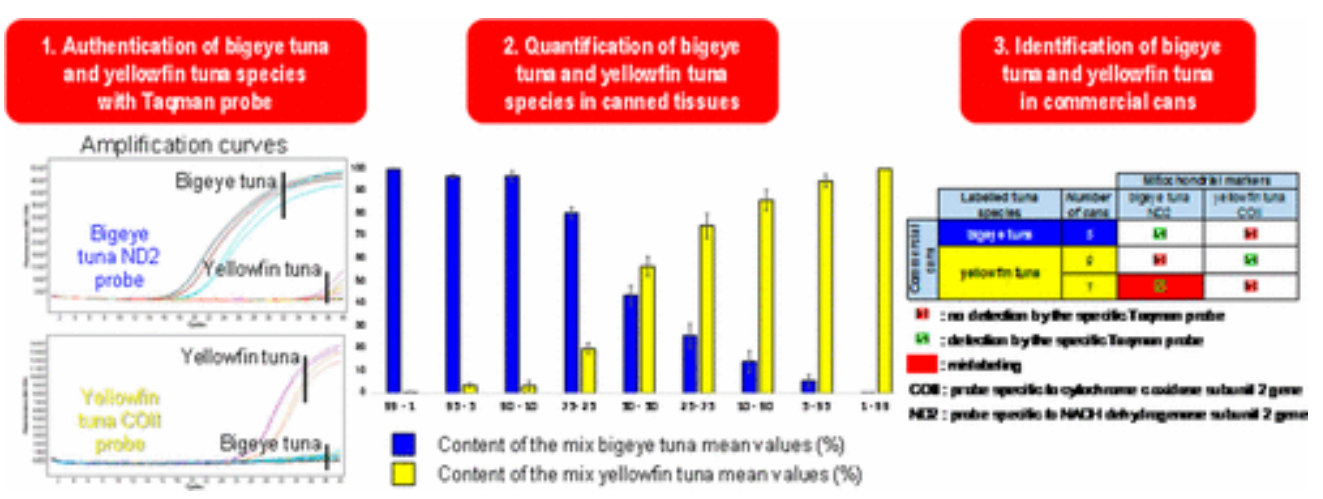

Keywords : authentication, bigeye tuna (Thunnus obesus), canned products, qPCR, quantification, species identification, TaqMan, tuna, yellowfin tuna (Thunnus albacares)

\section{Introduction}

Recent years have been marked by various food scandals such as 'Horsegate' (meat adulteration crisis in Europe in 2013), and the results of fish products mislabeling studies ${ }^{1,2}$. These events have highlighted the need: to set up an enhanced traceability system to improve quality process in industries; to reinforce consumer protection; and to reduce fraudulent activities. Seafoods are in the 'top ten' food products that are most likely to be subject of fraud ${ }^{3}$. Among these is one of the major marine species captured in $2012^{4}$, tuna, which represents an important economic value in the canning industry. According to the European 
legislation, mixing of tuna species in tuna cans is strictly forbidden ${ }^{5}$. However, substitutions between tuna species could appear during the filleting and canning process when external morphological characteristics, such as dorsal fins or finlets, are removed and fillets with similar appearance and texture are obtained. Furthermore, difficulties exist in identifying juveniles of bigeye tuna (Thunnus obesus, Lowe, 1839) and yellowfin tuna (Thunnus albacares, Bonnaterre, 1788) due to their similarity ${ }^{6}$. Moreover, these two species are often captured together from the same schools, particularly around the fish aggregation devices $(\mathrm{FADs})^{7}$, which are extensively used nowadays, resulting in potential substitutions. It was these observations that led this study to focus on these two particular species.

Several methods have been developed to identify species when the flesh is raw or cooked. Prior to the 1990s, the most used technique was the isoelectric, which focused on proteins (IEF) based on sarcoplasmic protein profiles $^{8}$. However, sterilization, which takes place during canning process, induces an irreversibly denaturation of proteins ${ }^{9}$. Furthermore, IEF is sometimes of no value in discriminating fish species within families such as scombridae (mackerels, tunas, and bonitos) $^{9}$. DNA however, represents a great advantage over proteins as it is stable at high temperatures, is present in all cells of the animal, and is endowed with a greater variability linked to genetic codes ${ }^{10}$. Consequently, biomolecular DNA techniques to identify fish species, including tuna species, have been developed for more than 20 years ${ }^{11}$. DNA degrades during heat treatment into small fragments ${ }^{12}$, but these are nevertheless, informative enough to differentiate even closely related tuna species ${ }^{11,13}$. Although the regions of both nuclear DNA (nDNA) and mitochondrial DNA (mtDNA) can be amplified by a polymerase chain reaction $(\mathrm{PCR})^{14}, \mathrm{mtDNA}$ has preferentially been used for authentication of the species, in particular when the starting sample has suffered intense heat treatments ${ }^{15}$. Concerning canned tuna, most studies show a preference to mtDNA in relation to nDNA because of its relative abundance and its circular structure, which provides greater resistance 
to thermal degradation ${ }^{15,16,17}$. It has actually been shown that intense heating, as applied in the processing of canned tuna, highly degrades DNA, cleaving it into tiny fragments. The average size of DNA fragments for canned products is between $<100$ and 360 bp compared to that of $\leq 20000 \mathrm{bp}$ for frozen products ${ }^{12,18}$. The mitochondrial gene cytochrome $\mathrm{b}$ has been one of the most commonly used for DNA-based fish species identification analysis; used extensively to identify flatfish, gadoids, eels, anchovies, and scombrids ${ }^{19}$. Nowadays, other genes are also used as markers to differentiate between fish species, like the cytochrome oxidase I (COI) coding gene, which is extensively used in the Barcode of Life project ${ }^{20}$, and its declination for fish in the Fish Barcode of Life initiative (FISH-BOL) ${ }^{21}$. Nevertheless, a number of studies have shown that the cytochrome oxidase subunit 1 gene was not necessarily the best candidate to differentiate between species of tuna ${ }^{22,23}$. A large range of DNA-based methods have been developed to identify scombrid species, mainly using mitochondrial gene fragments as markers ${ }^{22,24,25,26}$. Previous studies have used real time PCR with TaqMan probe methods to identify tuna species ${ }^{27,28}$. However, in most of these studies, real time PCR was mainly used for identification of the different tuna species. According to current knowledge, no method exists to quantify the amount of DNA from bigeye tuna and yellowfin tuna in a mix.

Thus, the aim of this study was to develop a routine TaqMan-based qPCR method to identify and quantify bigeye tuna and yellowfin tuna in canned products. DNA markers were focused on to distinguish bigeye tuna from yellowfin tuna, which are genetically closely related. The first step of this study was to design a specific TaqMan probe that would allow the identification of these two species. The second step was to develop two comparative quantitative methods to determine the percentage of each of these two species in mixed canned tuna products.

\section{Materials and methods}


75

\section{Samples collection}

\section{Raw material}

The two species of tuna being studied were purchased from commercial fishing vessels by the 'innovation platform for aquatic products' (Plateforme d'Innovation Nouvelles Vagues, (PFINV), Boulogne sur Mer, France, http://pfinouvellesvagues.com/?lang=en). Entire individuals of bigeye tuna and yellowfin tuna were sampled, and originated from the Atlantic, Pacific, and Indian oceans (10 individuals per ocean and per species). Before filleting, individuals were identified according to morphological characters using identification keys from the FAO Species Catalogue ${ }^{29}$. A piece of muscle tissue was sampled from each individuals and was used in the preliminary studies on raw tissue for the development of the primers and TaqMan probe. The remaining fillets were stored at $-20^{\circ} \mathrm{C}$ until DNA extraction. Reference materials of scombrid specimens were provided by tissue collection from the French Research Institute for Exploitation of the Sea (Ifremer: http://wwz.ifremer.fr/institut eng/) in order to validate the developed "primers/probe systems".

\section{Canned tuna}

Twenty cans containing either yellowfin tuna or bigeye tuna (10 cans per fish species) were prepared by PFINV using the techniques applied in the canning industry in order to obtain standardized cans. The previously frozen fillets were thawed to a temperature of between 0 and $2^{\circ} \mathrm{C}$. Tins $($ diameter $=55 \mathrm{~mm}, 1 / 12$ can $)$ were then filled with $80 \mathrm{~g}$ of raw flesh and brine. Cans were crimped and sterilized at $116^{\circ} \mathrm{C}$ to the sterilizing value (Fo) for $7 \mathrm{~min}$.

In order to simulate involuntary and voluntary rate substitutions in canned products, tuna cans of different mixtures of tuna fillets were prepared according to the following bigeye tuna/yellowfin tuna ratios: 99/1; 95/5; 90/10;75/25; 50/50;25/75; 10/90; 5/95 and 1/99 (e.g. the can containing the mix bigeye tuna/yellow fin tuna $75 / 25$ was made with $75 \%$ of bigeye 
tuna and $25 \%$ of yellowfin tuna). For each mix, cans were prepared in quadruplicate by PFINV following the same process.

Finally, 29 commercial tuna cans were purchased randomly from local markets to validate the method. They were labelled as yellowfin tuna (10), bigeye tuna (5), albacore (3) and skipjack tuna (11).

\section{DNA Extraction}

Before DNA extraction, brine was removed and tuna flesh was drained on filter paper. Two washing steps were followed: firstly with $70 \%$ ethanol, and then secondly with distilled water to eliminate any potential PCR inhibitors. After washing and drying, all flesh contained within the cans was finally homogenized using a mixer (Philips, France).

DNA extraction was performed according to the protocol described by Jérôme et al. $(2003)^{30}$.

Concentration and purity of extracted DNA were determined by measuring the absorbance of the DNA extracts at $260 \mathrm{~nm}$, checking for protein impurities at $280 \mathrm{~nm}$ and organic compound contamination at $230 \mathrm{~nm}$ using a spectrophotometer (Denovix, La Madeleine, France). The DNA extracts were stored at $-20^{\circ} \mathrm{C}$ until use.

\section{Primers and probe design}

Primers and probe sequences were specifically designed to identify bigeye and yellowfin tuna. DNA sequences of different scombrid species were obtained from GenBank (National Center for Biotechnology Information, www.ncbi.nlm.nih.gov/). Alignments of DNA sequences were performed using Multalin software ${ }^{31,32}$ to find conserved specific sites for species identification and to identify intraspecific variations. Following this study, fragments of the NADH dehydrogenase subunit 2 (ND2) gene was selected for bigeye tuna identification, and the cytochrome c oxidase subunit 2 (COII) gene for yellowfin tuna identification (Table 1). Moreover, sequence alignments of mitochondrial $12 \mathrm{~S}$ rRNA gene were realized for the two 
124 species and a short 12S rRNA fragment gene (Table 1) was selected to be used as an 125 endogenous gene.

126 Primers and TaqMan probes (Table 2) were designed using Primer3Plus software 127 (http://www.bioinformatics.nl/cgi-bin/primer3plus/primer3plus.cgi). Hydrolysis probes were labeled with carboxyfluorescein fluorescent reporter dye (FAM) on 5'-end and with a quencher (BHQ1) on the 3'-end. Primers and probe were synthesized by TibMolBiol (Berlin, Germany).

\section{Quantitative real-time PCR conditions}

132 PCR reactions were carried out in a total volume of $20 \mu \mathrm{L}$ containing $10 \mathrm{ng} / \mu \mathrm{L}$ of DNA 133 template per well, $0.5 \mu \mathrm{M}$ of each primer, $0.2 \mu \mathrm{M}$ of probe, $10 \mu \mathrm{L}$ of PCR LightCycler 480 134 Probe Master (Roche, France) and RNAse/DNAse-free distilled water to adjust to the final 135 volume (Roche, France).

PCR assays were performed in the LightCycler 480 thermocycler (Roche, France) under the following conditions: $95^{\circ} \mathrm{C}$ for $10 \mathrm{~min}$, followed by 40 cycles $95^{\circ} \mathrm{C}$ for 15 seconds, and $60^{\circ} \mathrm{C}$ for $1 \mathrm{~min}$.

139 Fluorescence data were analyzed using the LightCycler 480 software (LightCycler ${ }^{\circledR}$ SW 140 1.5.1). Each quantification cycle $(\mathrm{Cq})$ value represented the average of $\mathrm{Cq}$ from three 141 replicates.

\section{qPCR amplification efficiency and standard curves}

Standard curves were performed with the DNA extracted from standardized cans prepared by PFINV containing only one species: yellowfin tuna or bigeye tuna. Standard curves for each species were the result of mixing DNA from several specimens. Ten-fold dilutions series of bigeye tuna and yellowfin tuna DNA extracts ranging from 100 to $0.01 \mathrm{ng} / \mu \mathrm{L}$ were utilized to

147 perform qPCR standard curves. PCR amplification efficiency of each primer/TaqMan probe system (ND2, COII and 12S - Table 2) was calculated. Standard curves corresponding to Cq 
149 for each DNA dilution were constructed using the Lightcycler 480 software. The linear 150 correlation between $\mathrm{Cq}$ and initial concentration of standard samples $\left(\mathrm{N}_{0}\right)$ is: $\mathrm{Cq}=\mathrm{a} \cdot \log \left(\mathrm{N}_{0}\right)$

$151+b$, where ' $a$ ' is the slope and ' $b$ ' is the intercept. Values of amplification efficiency $\left(E=\left(10^{-}\right.\right.$

$\left.152^{1 / a}\right)$ ) were calculated from the slopes of standard curves. For example, a slope of -3.7 153 corresponds to a PCR efficiency of: $10^{-1 /-3.7}=1.86$, namely, a PCR efficiency of $86 \%$.

\section{Quantification methods}

155 DNA extracted from standardized cans containing binary mixtures of bigeye and yellowfin 156 tunas was used to develop the two quantification methods. Four cans of each mixture 157 condition were analyzed, and for each can, DNA extracts were performed in quadruplicate. 158 Each DNA extract gave rise to a double PCR analysis. This corresponded to 32 qPCR 159 analysis for each mixture condition.

160

161

162

163

164

165

166

167

Method based on absolute quantification with standard curves

The amounts of yellowfin tuna ([T.alb]) and bigeye tuna ([T.obe]) DNA in binary mixtures were deduced from the corresponding qPCR standard curves for each species. These measurements were transformed into percentages of one species ( $\%$ T.alb or $\%$ T.obe) according to the following equations:

$[$ Total DNA of tuna $]=[$ T.alb $]+[$ T.obe $]$

Equation 1: yellowfin tuna (Thunnus albacares) content $(\%)=\frac{[\text { T.alb }]}{[\text { Total DNA of tuna }]} * 100$

Equation 2: bigeye tuna (Thunnus obesus) content $(\%)=\frac{[\text { T.obe }]}{[\text { Total DNA of tuna }]} * 100$

Method based on relative quantification with an endogenous gene

For each studied tuna species, two independent standard curves were built in parallel, one was established for the target genes (ND2 or COII) and the other one for the endogenous $12 \mathrm{~S}$ rRNA gene. Amounts of target and endogenous genes in samples were then extrapolated from 
172 the established standard curves. The percentages of each fish species in can samples were

173 obtained following the equations previously used ${ }^{33}$ :

174 Equation 3: yellowfin tuna (Thunnus albacares) content $(\%)=\frac{[\mathrm{T} . \mathrm{alb}]}{[12 \mathrm{~S} \mathrm{rRNA}]} * 100$

175 Equation 4: bigeye tuna (Thunnus obsesus) content $(\%)=\frac{[\text { T.obe }]}{[12 \mathrm{~S} \mathrm{rRNA}]} * 100$

\section{Specificity and sensitivity}

177 qPCR amplifications of serial dilutions of DNA extracts for the two species were performed 178 to determine the limit of detection (LOD) and the limit of quantification (LOQ) values. The 179 calculation of LOD and LOQ were established following those of previous studies ${ }^{34}$. The LOD was assessed as the lowest amount of tuna-DNA that could be reliably distinguished from the blank matrix, whereas the LOQ was assessed as the lowest concentration at which the amount of tuna-DNA could not be reliably detected.

\section{Statistical Analyses}

Determination coefficients $\left(\mathrm{R}^{2}\right)$ were calculated and data were analyzed by the chi-square test using PAleontological STatistics (PAST) software (version.3.07) to compare percentages obtained with the real values. Cq values were compared using the independent t-test. Statistical significance was set at $\mathrm{p}<0.05$.

\section{Results and discussion}

\section{Design of primers and probe from interspecific and intraspecific DNA variation studies}

The first step of this work consisted in the development of two specific primer/TaqMan systems to identify and quantify bigeye tuna and yellowfin tuna by qPCR analysis. An interspecific genetic variability study among all mitochondrial molecular markers based on the availability of DNA sequences in GenBank database has been investigated to determine discriminatory regions for specific primer and probe design. Results of multiple mitochondrial 
195 DNA sequence alignments including the eight recognized species of Thunnus and seven 196 selected bonitos (Table 1) revealed a high degree of similarity between these species as 197 previously related ${ }^{35}$. Informative sites are limited to only one or two nucleotides per $300 \mathrm{bp}$ 198 sequences due to the low variability in nucleotide sequences between yellowfin tuna and 199 bigeye tuna. This lack of polymorphism makes it difficult to correct species identification 200 with standard PCR methodology. It was necessary to develop a qPCR TaqMan-based 201 methodology to identify the two tuna species and then to quantify the amount of DNA of each 202 of the two tuna species.

203 Among all mitochondrial genes, only cytochrome c oxidase subunit 2 (COII) and NADH 204 dehydrogenase subunit 2 (ND2) genes (table 1) showed discriminatory regions which would 205 allow the identification of the two tuna species compared to the other scombridae species 206 (data not shown). Informative regions of ND2 and COII were selected for design of primers 207 and probe to respectively identify bigeye tuna and yellowfin tuna. Subsequent investigations 208 of intraspecific variations for these two genes showed no intraspecific variability for bigeye 209 tuna and yellowfin tuna sequences.

210 Primers and probe that allowed characterization of yellowfin tuna were obtained from the 211 COII gene sequence (AY971768.1), whereas those designed for bigeye tuna identification 212 were obtained from the ND2 gene (NC_014059.1). The size of each amplicon was 99 bp and $213198 \mathrm{bp}$ for bigeye tuna and yellowfin tuna, respectively. The combination of primers and 214 species-specific probe was called the "primers/probe system" (Table 2).

215 Furthermore, based on 12S rRNA sequences, 'universal' primers, allowing amplification of a 216 common reference gene region, and probe were designed to recognize eight species of 217 Thunnus and seven bonitos. Forward and reverse primers and TaqMan probe were designed 218 from the 12S rRNA sequence (AB176811.1) giving a fragment of $107 \mathrm{bp}$ (Table 2). 
Many studies have been conducted for the development of identification methods of canned tuna or bonito species. Bartlett and Davidson (1991) were the first authors to develop a molecular method based on DNA sequencing of $307 \mathrm{bp}$ mitochondrial cytochrome $\mathrm{b}$ gene to identify four tuna species (T. thynnus, T. obesus, T. albacares, T. alalunga $)^{13}$. They have further developed the FINS ((Forensically Informative Nucleotide Sequencing) method ${ }^{36}$. In the case of canned tuna, short DNA fragments have to be amplified by PCR, because the severe heat treatment during the tuna canning process leads to heavy degradation of $\mathrm{DNA}^{37}$. Unseld et al. (1995) showed that it is possible to distinguish between some tuna and bonito species by amplification and sequencing of a short $59 \mathrm{bp}$ DNA fragment (123 bp including primers) of the mitochondrial cytochrome $b$ gene ${ }^{11}$. Nevertheless, they failed to discriminate bigeye tuna from yellowfin that differed by only one nucleotide in the gene fragment studied. Since sequencing was a relatively long and expensive technique, various methods including the use of PCR coupled to other identification tools have been also used to authenticate tuna

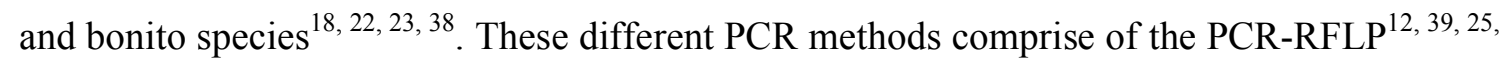
40, 41, the PCR SSCP ${ }^{42,43}$, the PCR-ELISA ${ }^{44}$, or the RT-PCR ${ }^{45,28,46}$. However, all these described methods may be used to identify tuna species, but not to quantify their amount of DNA. A real-time PCR or qPCR methodology based on a fragment of about $100 \mathrm{bp}$ of the 16S rRNA gene ${ }^{27}$ was first developed in 2005 on canned tuna to identify and quantify two mixed tuna species, albacore and yellowfin tuna.

Our two 'primers/probe systems' were first tested on DNA extracted from raw muscle tissues of the two-targeted species. Specific fluorescence emission was detected for each targeted species at the optimal conditions of qPCR used (Tm primers, primers and probe concentrations, DNA concentration etc...). In a second step, the two 'primers/probe systems' were tested on DNA extracted from the reference tuna cans containing only one of the two tuna species. A delay of $\mathrm{Cq}$ values for canned tissue DNA versus $\mathrm{Cq}$ values for raw tissue 
245 DNA was noticed for the same quantity of DNA, probably due to the impact of sterilization

246 on DNA. These results showed that yellowfin tuna species-specific TaqMan primers and

247 probe could identify yellowfin tuna species in cans. The mean Cq obtained from primers and

248 probe designed for yellowfin tuna (Talb_COII) was $21.04 \pm 1.38$ (mean $\pm \mathrm{sd}$ ). No amplification

249 was detected with this yellowfin tuna probe tested on bigeye tuna cans. Primers and probe 250 designed for bigeye tuna (Tobe_ ND2) amplified ND2 sequences of DNA from cans 251 containing bigeye tuna species with an averaged $\mathrm{Cq}$ value of $22.10 \pm 1.18$. Fluorescence 252 emission for probe designed for bigeye tuna (Tobe_ ND2) was also observed on DNA 253 extracted from yellowfin tuna cans but with a mean $\mathrm{Cq}$ of $34.36 \pm 1.05$. These differences 254 between $\mathrm{Cq}$ values tested with Chi-square test were statistically significant $(\mathrm{p}<0.001)$ and 255 allowed the discrimination between bigeye tuna and yellowfin tuna.

\section{Specificity of the two 'primers/probe systems'}

For canned products, standard curves were obtained with an efficiency of $92.4 \% \pm 5.4$ for bigeye tuna and $99.8 \% \pm 5.9$ for yellowfin tuna. The LOD and LOQ were evaluated to 0.01 $\mathrm{ng} / \mu \mathrm{L}$ for bigeye tuna and yellowfin tuna.

The species-specificity of the two 'primers/probe systems' was also evaluated by testing DNA amplification from raw tissues of the ten following tuna and bonito species: albacore (Thunnus alalunga), Atlantic bluefin tuna (Thunnus thynnus), longtail tuna (Thunnus tonggol), blackfin tuna (Thunnus atlanticus), Atlantic bonito (Sarda sarda), bullet tuna (Auxis rochei), kawakawa (Euthynnus affinis), frigate tuna (Auxis thazard), little tunny (Euthynnus alletteratus), and skipjack tuna (Katsuwonus pelamis). No fluorescence signal was recorded with DNA templates from albacore, Atlantic bonito, blackfin tuna, bullet tuna, frigate tuna, kawakawa, or little tunny. For Atlantic bluefin tuna, a signal was recorded with the bigeye tuna primer-probe system, with a $\mathrm{Cq}$ averaging at $20.22 \pm 0.49$, near to that obtained for bigeye tuna (averaged at $17.9 \pm 1.14$ for raw tissues). However, as Atlantic Bluefin tuna is not 
used for tuna cans but almost exclusively in sashimi and sushi dishes, this lack of specificity here is not considered to be an issue. For longtail tuna, only one reference sample was tested, and a $\mathrm{Cq}$ of $24.79 \pm 0.15$ was obtained by amplification with the bigeye tuna primers/probe system'. This $\mathrm{Cq}$ value was close to the $\mathrm{Cq}$ obtained for bigeye tuna $(17.9 \pm 1.14$ for raw tissues). Due to the lack of other reference samples, this result has not been confirmed yet.

\section{Assessment of quantification on standardized mixtures}

A large number of identification techniques are based on mitochondrial genes as molecular markers because mtDNA allows greater sensitivity of the method. However, the problem caused by the use of mitochondrial DNA of one species lies in the fact that there is a variable number of copies of mtDNA according to individual, age, or nature of the extracted tissue $(\text { muscle, fin... })^{47,48}$. Nowadays, two approaches of quantification with real time PCR methodology based on different calculation $\operatorname{modes}^{49}, 50,27,33$ exist: either relative quantification with an endogenous gene; or absolute quantification. To our knowledge, only one study has been published on the quantification of mixed tuna species in $\operatorname{con}^{27}$ and, in the particular case of the two closely related species -bigeye and yellowfin tuna- no paper can be found in the literature. In addition to the distinction between these two species, it was necessary to develop qPCR methods for quantifying the presence of a species below a specified threshold. This limit has been set at one percent following the request of the tuna canning industry, which allows discrimination between voluntary substitutions from involuntary substitutions.

This study's methodology was tested on canned mixtures containing different percentages of bigeye tuna and yellowfin tuna species.

\section{Method based on absolute quantification with standard curves}

The two targeted mitochondrial genes (COII for yellowfin tuna, and ND2 for bigeye tuna) were used for absolute quantification. Standard curves were established for the two tuna 
species, which allowed the calculating of the DNA quantity for each tuna species, following equations 1 and 2. This method postulated on the fact that amounts of mtDNA were equivalent in these two close species. The resulting percentages were statistically compared with the real values of the standardized mixtures based on the Chi-square test. No significant difference between the percentages experimentally calculated and those of the initial mixtures was shown, except for the results of cans containing 50\% of each species (Figure 1).

The results of this study highlighted the efficiency of this approach towards quantifying the presence of bigeye tuna and yellowfin tuna in cans containing mixtures of these two species.

\section{Method based on relative quantification with an endogenous gene}

Another strategy developed in this study for quantification of species in tuna cans is based on two targeted mitochondrial genes, namely, one species-specific gene for targeted species identification (COII for yellowfin tuna and ND2 for bigeye tuna), and in one endogenous gene - the $12 \mathrm{~S}$ rRNA gene that can be amplified, irrespective of the tuna species, with the same universal 'primers/probe system'. The calculation of relative quantification based on $\mathrm{Cq}$ variation between target and endogenous amplifications could not be used with bigeye tuna and yellowfin tuna samples cooked in cans as previously described by Lopez and Pardo ${ }^{27}$ on binary mixtures of sterilized tissue of albacore and yellowfin tuna. Lopez and Pardo found error up to $50 \%$, and they concluded ${ }^{2727272727272727}$ that it was not possible to express quantification with this method using these sterilized tuna species due to the degradation of DNA that exerts an influence in the calculation of Cq values. Consequently, we used a calculation method developed for the quantification of beef and pork fractions in minced meat ${ }^{33}$ to quantify bigeye tuna and yellowfin tuna in binary mixtures following equations 3 and 4. Calculated percentages were statistically compared with the expected values.

The results showed that the percentage calculations using the specific probe for bigeye tuna allowed the obtaining of a precise quantification only for the following percentages: 90,75 , 
25 and 5\%, showing that this method has limitations (Figure 2). On the other hand, the expected results were not conclusive using probe for yellowfin tuna when amounts of yellowfin tuna were greater than $50 \%$ (data not shown). The amounts of bigeye tuna or yellowfin tuna in a mix of these two species were determined with equation 4 , allowing the calculation of the amount of bigeye tuna and yellowfin tuna.

\section{Study with commercial tuna cans}

The suitability of this study's 'primers/probe systems' for canned tuna authentication was subsequently tested on twenty nine commercial cans; labelled as albacore tuna (3 cans), bigeye tuna ( 5 cans), skipjack tuna (11 cans), and yellowfin tuna (10 cans). The investigation showed that DNA from cans labelled as albacore tuna or skipjack tuna species were not amplified with primers and probe specific to bigeye tuna or yellowfin tuna. The cans labelled as bigeye tuna were confirmed to be processed with this species when analyzed with primers and probe specific to bigeye tuna. While this analysis confirmed the presence of yellowfin tuna in nine cans, a single commercial can, labeled as yellowfin tuna, seemed to contain bigeye tuna flesh, suggesting a mislabeling. In addition, identification for the presence of skipjack tuna was performed on commercially labelled skipjack tuna, bigeye tuna, and yellowfin tuna cans, following a methodology previously developed in the authors' laboratory (unpublished). The results showed that all the 11 commercial cans labeled as skipjack tuna in actuality contained skipjack tuna. Skipjack tuna was not detected in any commercial can labeled as bigeye tuna or albacore tuna. Among the ten commercial cans labeled as yellowfin tuna, five cans were composed of a mixture of yellowfin tuna and skipjack tuna. These results suggest the presence of different species in yellowfin tuna cans, or mislabeling during the production, which the tuna canning industry will have to address.

To conclude, the two 'primers/probe systems' developed in this study have been used to: differentiate bigeye tuna from yellowfin tuna; and quantify them in canned products. Analysis 
of 29 commercial tuna cans permitted the detection of a labeling error between bigeye tuna and yellowfin tuna. The two quantification methods based on standard curves or endogenous gene allowed the estimating of the level of content of each of the two targeted species in mixtures. The authors consequently suggest the following protocols to discriminate these two very close species: i) identify the presence of one of, or both of the species in tuna cans with primers and the Taqman probe designed in this study, ii) (in the case of the presence of more than one species) quantify the amount of each species using the method based on absolute quantification of these two species with standard curves. The second method based on bigeye tuna relative quantification using $12 \mathrm{~S}$ rRNA endogenous gene could be used as confirmation. This identification and quantification methodology should help laboratories to contribute to traceability concerning canned tuna in order to obtain responses about substitution or fraud.

\section{Acknowledgments}

This study is a part of the IDThon project supported by the Nord Pas de Calais council and Bpi France. Daline BOJOLLY is grateful to the Nord Pas de Calais council and "Plateforme d'Innovation Nouvelles Vagues" for their financial support of her $\mathrm{PhD}$. The authors acknowledge Stéphanie COPIN and Annick ROBERT-PILLOT for their technical advices in probe construction.

\section{References}

1. Warner, K.; Timme, W.; Lowell, B.; Hirschfield, M. In Oceana study reveals seafood fraud nationwide, 2013; 2013; pp 1-69.

2. Bénard-Capelle, J.; Guillonneau, V.; Nouvian, C.; Fournier, N.; Le Loët, K.; Dettai, A., Fish mislabelling in France: substitution rates and retail types. PeerJ 2015, 2, e714.

3. Moore, J. C.; Spink, J.; Lipp, M., Development and application of a database of food ingredient fraud and economically motivated adulteration from 1980 to 2010. J. Food Sci. 2012, 77, R118-R126.

4. $\quad$ FAO, The state of world fisheries and aquaculture. 2014.

5. Council regulation 1536, Council regulation (EEc) $\mathrm{n}^{\circ} 1536 / 92$ of 9 june 1992 laying down common marketing standards for preserved tuna and bonito. Council regulation (EEC) 1992, 1536.

6. Nakamura, I.; Séret, B., Field identification key of tunas of the genus Thunnus. Cybium 2002, 26, 141145.

7. Miyake, M. P., Recent developments in the tuna industry : stocks, fisheries, management, processing, trade and markets. Food and Agriculture Organization of the United Nations: Rome, 2010. 
8. Etienne, M.; Jérôme, M.; Fleurence, J.; Rehbein, H.; Kündiger, R.; Mendes, R.; Costa, H.; PérezMartin, R.; Piñeiro-Gonźlez, C.; Craig, A.; Mackie, I.; Malmheden Yman, I.; Ferm, M.; Martínez, I.; Jessen, F.; Smelt, A.; Luten, J., Identification of fish species after cooking by SDS-PAGE and urea IEF: a collaborative study. J. Agric. Food Chem. 2000, 48, 2653-2658. . Mendez, M.; Rehbein, H., Challenges in the identification of species of canned fish. Trends Food Sci. Technol. 1999, 10, 9-14.

10. Mackie, I., Authenticity of fish. In Food authentication, Springer ed.; Ashurt, P. R.; Dennis, M. J., Eds. Blackie Academic and Professional: London, 1996; pp 140-170.

11. Unseld, M.; Beyermann, B.; Brandt, P.; Hiesel, R., Identification of the species origin of highly processed meat products by mitochondrial DNA sequences. PCR Methods Appl. 1995, 4, 241-243.

12. Quinteiro, J.; Sotelo, C. G.; Rehbein, H.; Pryde, S. E.; Medina, I.; Perez-Martin, R. I.; Rey-Mendez, M.; Mackie, I. M., Use of mtDNA direct polymerase chain reaction (PCR) sequencing and PCR-restriction fragment length polymorphism methodologies in species identification of canned tuna. J. Agric. Food Chem. 1998, 46, 1662-1669.

13. Bartlett, S. E.; Davidson, W. S., Identification of Thunnus tuna species by the Polymerase Chain Reaction and direct sequence analysis of their mitochondrial cytochrome b genes. Can. J. Fish. Aquat. Sci. 1991, 48, 309-317.

14. Asensio, L., PCR-based methods for fish and fishery products authentication. Trends Food Sci. Technol. 2007, 18, 558-566.

15. Borgo, R.; Souty-Grosset, C.; Bouchon, D.; Gomot, L., PCR-RFLP analysis of mitochondrial DNA for identification of snail meat species. J. Food Sci. 1996, 61, 1-4.

16. Bossier, P., Authentication of seafood products by DNA patterns. J. Food Sci. 1999, 64, 189-193.

17. Civera, T., Species identification and safety of fish products. Vet Res Commun 2003, 27, 481-489.

18. Rasmussen, R. S.; Morrissey, M. T., Application of DNA-based methods to identify fish and seafood substitution on the commercial market. Compr. Rev. Food Sci. Food Saf. 2009, 8, 118-154.

19. Rasmussen, R. S.; Morrissey, M. T., DNA-based methods for the identification of commercial fish and seafood species. Compr. Rev. Food Sci. Food Saf. 2008, 7, 280-295.

20. Hebert, P. D.; Cywinska, A.; Ball, S. L., Biological identifications through DNA barcodes. Proc. R. Soc. London, Ser. B 2003, 270, 313-321.

21. Ward, R. D.; Hanner, R.; Hebert, P. D. N., The campaign to DNA barcode all fishes, FISH-BOL. J. Fish Biol. 2009, 74, 329-356.

22. Viñas, J.; Tudela, S., A validated methodology for genetic identification of tuna species (genus Thunnus). PLoS One 2009, 4, e7606.

23. Pedrosa-Gerasmio, I. R.; Babaran, R. P.; Santos, M. D., Discrimination of juvenile yellowfin (Thunnus albacares) and bigeye (T. obesus) tunas using mitochondrial DNA control region and liver morphology. PLoS One 2012, 7, e35604.

24. Chow, S.; Kishino, H., Phylogenetic relationships between tuna species of the genus Thunnus (Scombridae: Teleostei): inconsistent implications from morphology, nuclear and mitochondrial genomes. $J$. Mol. Evol. 1995, 41, 741-748.

25. Ram, J. L.; Ram, M. L.; Baidoun, F. F., Authentication of canned tuna and bonito by sequence and restriction site analysis of polymerase chain reaction products of mitochondrial DNA. J. Agric. Food Chem. 1996, 44, 2460-2467.

26. Michelini, E.; Cevenini, L.; Mezzanotte, L.; Simoni, P.; Baraldini, M.; De Laude, L.; Roda, A., Onestep triplex-polymerase chain reaction assay for the authentication of yellowfin (Thunnus albacares), bigeye (Thunnus obesus), and skipjack (Katsuwonus pelamis) tuna DNA from fresh, frozen, and canned tuna samples. J. Agric. Food Chem. 2007, 55, 7638-7647.

27. Lopez, I.; Pardo, M. A., Application of relative quantification TaqMan real-time polymerase chain reaction technology for the identification and quantification of Thunnus alalunga and Thunnus albacares. J. Agric. Food Chem. 2005, 53, 4554-4560.

28. Chuang, P.-S.; Chen, M.-I.; Shiao, J.-C., Identification of tuna species by a real-time polymerase chain reaction technique. Food Chem. 2012, 133, 1055-1061.

29. Collette, B. B.; Nauen, C. E., Scombrids of the words. FAO, Rome (Italy): 1983.

30. Jérôme, M.; Lemaire, C.; Bautista, J. M.; Fleurence, J.; Etienne, M., Molecular phylogeny and species identification of sardines. J. Agric. Food Chem. 2003, 51, 43-50.

31. Corpet, F., Multiple sequence alignment with hierarchical clustering. Nucleic Acids Res. 1988, 16, 10881-10890.

32. Kumar, S.; Nei, M.; Dudley, J.; Tamura, K., MEGA: a biologist-centric software for evolutionary analysis of DNA and protein sequences. Briefings Bioinf. 2008, 9, 299-306. 

PCR method for the quantification of beef and pork fractions in minced meat. Food Chem. 2015, 169, 305-313. 34. Bustin, S. A.; Benes, V.; Garson, J. A.; Hellemans, J.; Huggett, J.; Kubista, M.; Mueller, R.; Nolan, T.; Pfaffl, M. W.; Shipley, G. L.; Vandesompele, J.; Wittwer, C. T., The MIQE Guidelines: Minimum Information for Publication of Quantitative Real-Time PCR Experiments. Clin. Chem. (Washington, DC, U. S.) 2009, 55, 611-622.

35. Bottero, M. T.; Dalmasso, A.; Cappelletti, M.; Secchi, C.; Civera, T., Differentiation of five tuna species by a multiplex primer-extension assay. J. Biotechnol. 2007, 129, 575-580.

36. Bartlett, S. E.; Davidson, W. S., FINS (forensically informative nucleotide sequencing): a procedure for identifying the animal origin of biological specimens. BioTechniques 1992, 12, 408-11.

37. Quinteiro, J.; Santaclara, F. J.; Rehbein, H., Authenticity of canned seafood. In Quality parameters in canned seafood, A.G. Cabado, J. M. V., Ed. Nova Science Publishers, Inc.: 2008; pp 135-158.

38. Botti, S.; Giuffra, E., Oligonucleotide indexing of DNA barcodes: Identification of tuna and other scombrid species in food products. BMC Biotechnol. 2010, 10, 1.

39. Pardo, M. A.; Pérez-Villareal, B., Identification of commercial canned tuna species by restriction site analysis of mitochondrial DNA products obtained by nested primer PCR. Food Chem. 2004, 86, 143-150.

40. Lin, W. F.; Shiau, C. Y.; Hwang, D. F., Identification of four Thunnus tuna species using mitochondrial cytochrome b gene sequence and PCR-RFLP analysis. J. Food Drug Anal. 2005, 13, 382-387.

41. Lin, W. F.; Hwang, D. F., Application of PCR-RFLP analysis on species identification of canned tuna. Food Control 2007, 18, 1050-1057.

42. Rehbein, H.; Mackie, I. M.; Pryde, S.; Gonzales-Sotelo, C.; Medina, I.; Perez-Martin, R.; Quinteiro, J.; Rey-Mendez, M., Fish species identification in canned tuna by PCR-SSCP: validation by a collaborative study and investigation of intra-species variability of the DNA-patterns. Food Chem. 1999, 64, 263-268.

43. Rehbein, H.; Mackie, I. M.; Pryde, S.; Ganzales-Sotelo, C.; Perez-Martin, R.; Quinteiro, J.; ReyMendez, M., Comparison of different methods to produce single-strand DNA for identification of canned tuna by single-strand conformation polymorphism analysis. Electrophoresis 1998, 19, 1381-1384.

44. Santaclara, F. J.; Velasco, A.; Pérez-Martín, R. I.; Quinteiro, J.; Rey-Méndez, M.; Pardo, M. A.; Jimenez, E.; Sotelo, C. G., Development of a multiplex PCR-ELISA method for the genetic authentication of Thunnus species and Katsuwonus pelamis in food products. Food Chem. 2015, 180, 9-16.

45. Dalmasso, A.; Fontanella, E.; Piatti, P.; Civera, T.; Secchi, C.; Bottero, M. T., Identification of four tuna species by means of Real-Time PCR and melting curve analysis. Vet Res Commun 2007, 31, 355-357.

46. Terio, V.; Di Pinto, P.; Decaro, N.; Parisi, A.; Desario, C.; Martella, V.; Buonavoglia, C.; Tantillo, M. G., Identification of tuna species in commercial cans by minor groove binder probe real-time polymerase chain reaction analysis of mitochondrial DNA sequences. Mol. Cell. Probes 2010, 24, 352-356.

47. Alonso, A.; Martín, P.; Albarrán, C.; García, P.; García, O.; Fernández De Simón, L.; GarcíaHirschfeld, J.; Sancho, M.; De La Rúa, C.; Fernández-Piqueras, J., Real-time PCR designs to estimate nuclear and mitochondrial DNA copy number in forensic and ancient DNA studies. Forensic Sci. Int. 2004, 139, 141149 .

48. Bottero, M. T.; Dalmasso, A., Animal species identification in food products: evolution of biomolecular methods. Vet. J. 2011, 190, 34-38.

49. Livak, K. J.; Schmittgen, T. D., Analysis of relative gene expression data using real-time quantitative PCR and the 2(-Delta Delta C(T)) method. Methods 2001, 25.

50. Bustin, S. A., Absolute quantification of mRNA using real-time reverse transcription polymerase chain reaction assays. J. Mol. Endocrinol. 2000, 25, 169-193. 


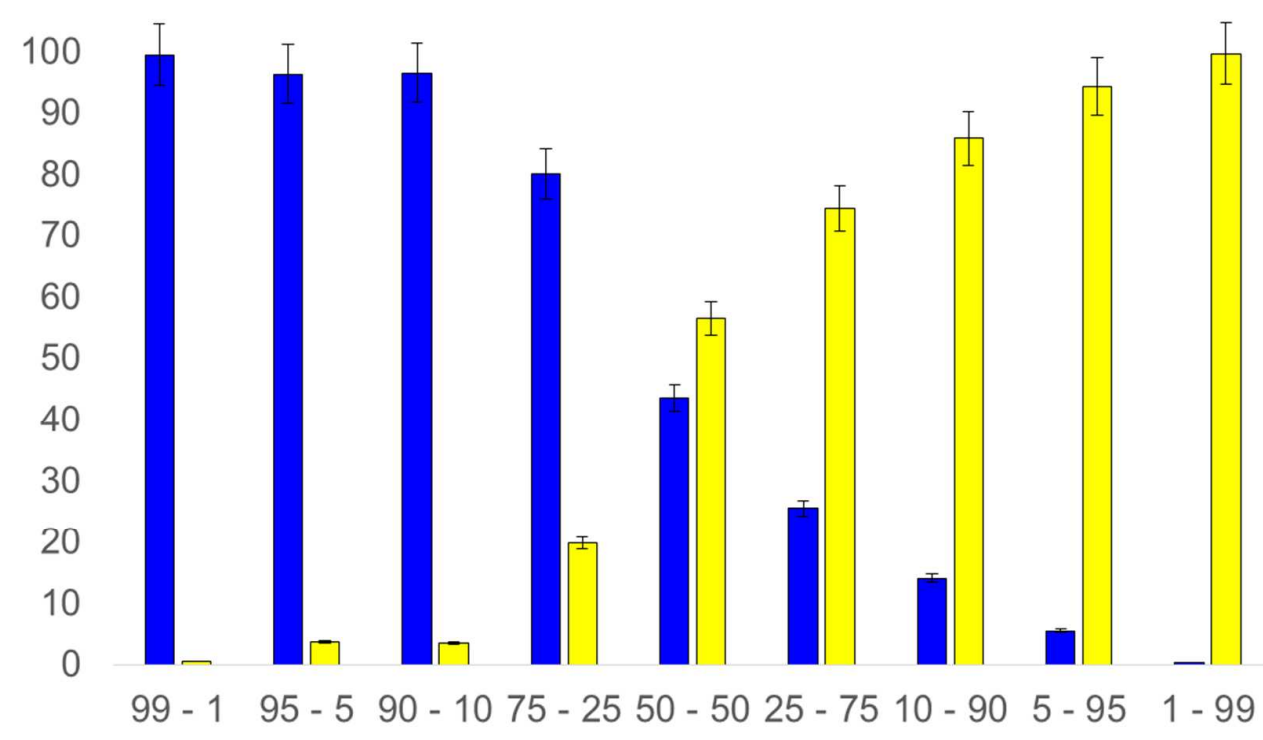

Figure 1: Quantification (in percentage) of binary mixtures of bigeye tuna and yellowfin tuna canned samples calculated with the method based on absolute quantification with standard curves. Blue histogram: average values of percentages of bigeye tuna; yellow histogram: average values of percentages of yellowfin tuna. Values on abscissa axis indicate expected theoretical percentages. Error bars indicate standard deviation in quadruplicates.

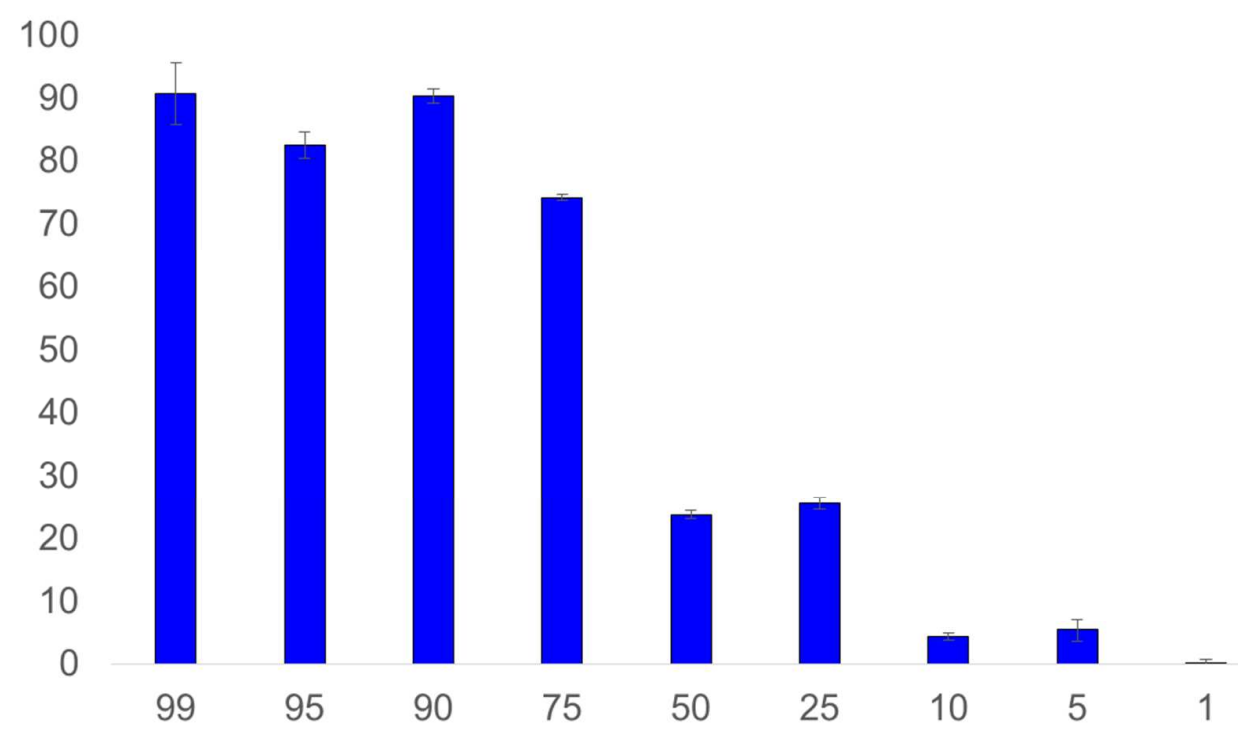

Figure 2: Average values of percentages of bigeye tuna species content processed with different quantities of bigeye tuna and yellowfin tuna calculated with the method based on relative quantification with the $12 \mathrm{~S}$ rRNA endogenous gene. Values on abscissa axis indicate expected theoretical percentages. Error bars indicate standard deviation in quadruplicates. 
Table 1: Genbank accession numbers of mitochondrial DNA sequences of cytochrome c oxidase subunit 2 (COII) gene, NADH dehydrogenase subunit 2 (ND2) gene, and 12S rRNA gene, for 15 scombridae species.

\begin{tabular}{|c|c|c|c|}
\hline \multirow[b]{2}{*}{ Scombridae species } & \multicolumn{3}{|c|}{ 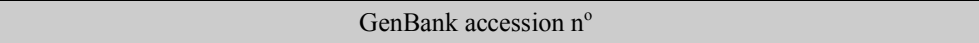 } \\
\hline & $\begin{array}{l}\text { cytochrome c oxidase } \\
\text { subunit } 2 \text { (COII) gene }\end{array}$ & $\begin{array}{l}\text { NADH dehydrogenase } \\
\text { subunit } 2 \text { (ND2) gene }\end{array}$ & 12S rRNA gene \\
\hline Yellowfin tuna / Thunnus albacares & $\begin{array}{c}\text { AY971768 } \\
\text { GU256528.1 } \\
\text { JN086153.1 } \\
\text { NC_014061.1 }\end{array}$ & $\begin{array}{c}\text { GU256528.1 } \\
\text { JN086153.1 } \\
\text { NC_014061.1 }\end{array}$ & $\begin{array}{c}\text { DQ874694.1 } \\
\text { GU256528.1 } \\
\text { HM003553.1 to HM003555.1 } \\
\text { HQ641701.1 } \\
\text { JN086153.1 } \\
\text { NC } 014061.1 \\
\end{array}$ \\
\hline Bigeye tuna / Thunnus obesus & $\begin{array}{c}\text { GU256525.1 } \\
\text { AY971769 } \\
\text { JN086152.1 } \\
\text { NC } 014059.1 \\
\end{array}$ & $\begin{array}{c}\text { GU256525.1 } \\
\text { JN086152.1 } \\
\text { NC_014059.1 }\end{array}$ & $\begin{array}{c}\text { GU256525.1 } \\
\text { HQ592316.1 to HQ592318.1 } \\
\text { JN086152.1 } \\
\text { NC } 014059.1\end{array}$ \\
\hline Albacore / Thunnus alalunga & $\begin{array}{c}\text { AB101291.1 } \\
\text { GU256526.1 } \\
\text { JN086151.1 } \\
\text { NC_005317.1 }\end{array}$ & $\begin{array}{c}\text { AB101291.1 } \\
\text { GU256526.1 } \\
\text { JN086151.1 } \\
\text { NC_005317.1 }\end{array}$ & $\begin{array}{c}\text { AB101291.1 } \\
\text { AB176804.1 } \\
\text { GU946542.1 } \\
\text { GU946543.1 } \\
\text { GU946544.1 } \\
\text { JN007517.1 to JN007526.1 } \\
\text { JN086151.1 } \\
\text { NC } 005317.1\end{array}$ \\
\hline Southern bluefin tuna / Thunnus maccoyii & $\begin{array}{c}\text { GU256523.1 } \\
\text { JN086150.1 } \\
\text { NC } 014101.1 \\
\end{array}$ & $\begin{array}{c}\text { GU256523.1 } \\
\text { JN086150.1 } \\
\text { NC 014101.1 } \\
\end{array}$ & $\begin{array}{c}\text { GU256523.1 } \\
\text { JN086150.1 } \\
\text { NC } 014101.1 \\
\end{array}$ \\
\hline Pacific bluefin tuna / Thunnus orientalis & $\begin{array}{c}\text { AB185022.1 } \\
\text { GU256524.1 } \\
\text { NC } 008455.1\end{array}$ & $\begin{array}{c}\text { AB185022.1 } \\
\text { GU256524.1 } \\
\text { NC } 008455.1\end{array}$ & $\begin{array}{c}\text { AB185022.1 } \\
\text { GU256524.1 } \\
\text { KF906721.1 } \\
\text { NC } 008455.1 \\
\text { NC } 008455.1 \\
\end{array}$ \\
\hline Northern bluefin tuna / Thunnus thynnus & $\begin{array}{c}\text { AB097669.1 } \\
\text { AY302574.2 } \\
\text { AY971770 } \\
\text { GU256522.1 } \\
\text { JN086149.1 } \\
\text { NC_004901.2 } \\
\text { NC_014052.1 }\end{array}$ & $\begin{array}{c}\text { AB097669.1 } \\
\text { AY302574.2 } \\
\text { DQ854690.1 } \\
\text { GU256522.1 } \\
\text { JN086149.1 } \\
\text { NC_004901.2 } \\
\text { NC_014052.1 }\end{array}$ & $\begin{array}{c}\text { AB097669.1 } \\
\text { AB176805.1 } \\
\text { AY302574.2 } \\
\text { DQ854647.1 } \\
\text { GU256522.1 } \\
\text { JN086149.1 } \\
\text { KF906720.1 } \\
\text { NC } 004901.2 \\
\text { NC } 014052.1 \\
\end{array}$ \\
\hline Longtail tuna / Thunnus tonggol & $\begin{array}{c}\text { HQ425780.1 } \\
\text { JN086154.1 } \\
\text { NC } 020673.1 \\
\end{array}$ & $\begin{array}{c}\text { HQ425780.1 } \\
\text { JN086154.1 } \\
\text { NC } 020673.1 \\
\end{array}$ & $\begin{array}{c}\text { HQ425780.1 } \\
\text { JN086154.1 } \\
\text { NC } 020673.1 \\
\end{array}$ \\
\hline Blackfin tuna / Thunnus atlanticus & KM405517.1 & KM405517.1 & DQ874693.1 \\
\hline Skipjack tuna / Katsuwonus pelamis & $\begin{array}{c}\text { AB101290.1 } \\
\text { AY971773 } \\
\text { GU256527.1 } \\
\text { JN086155.1 } \\
\text { NC_005316.1 }\end{array}$ & $\begin{array}{l}\text { AB101290.1 } \\
\text { JN086155.1 } \\
\text { GU256527.1 }\end{array}$ & $\begin{array}{c}\text { AB101290.1 } \\
\text { AB176808.1 } \\
\text { DQ874697.1 } \\
\text { GU256527.1 } \\
\text { HQ592295.1 to HQ592297.1 } \\
\text { JN086155.1 }\end{array}$ \\
\hline Atlantic bonito / Sarda sarda & AY971771.1 & $\begin{array}{l}\text { EU263832.1 } \\
\text { EU263833.1 }\end{array}$ & DQ874691.1 \\
\hline Orientalis bonito / Sarda orientalis & AY971772 & ns & ns \\
\hline Bullet tuna / Auxis rochei & $\begin{array}{l}\text { AB103467.1 } \\
\text { AB103468.1 } \\
\text { AB105165.1 } \\
\text { AY971774.1 } \\
\text { NC_005313.1 }\end{array}$ & $\begin{array}{l}\text { AB103467.1 } \\
\text { AB103468.1 } \\
\text { AB105165.1 } \\
\text { EU263836.1 } \\
\text { NC_005313.1 }\end{array}$ & $\begin{array}{c}\text { AB103467.1 } \\
\text { AB103468.1 } \\
\text { AB176811.1 } \\
\text { AB176810.1 } \\
\text { AB105165.1 } \\
\text { NC } 005313.1 \\
\end{array}$ \\
\hline Frigate tuna / Auxis thazard & $\begin{array}{l}\text { AB105447.1 } \\
\text { NC_005318.1 }\end{array}$ & $\begin{array}{c}\text { AB105447.1 } \\
\text { EU263837.1 } \\
\text { NC_005318.1 }\end{array}$ & $\begin{array}{c}\text { AB } 105447.1 \\
\text { AB } 176809.1 \\
\text { DQ874692.1 } \\
\text { NC } 005318.1 \\
\end{array}$ \\
\hline Kawakawa / Euthynnus affinis & AY971776.1 & ns & $\mathrm{ns}$ \\
\hline Little tunny / Euthynnus alletteratus & $\begin{array}{l}\text { AB099716.1 } \\
\text { AY971775.1 } \\
\text { NC_004530.1 }\end{array}$ & $\begin{array}{l}\text { AB099716.1 } \\
\text { NC_004530.1 }\end{array}$ & $\begin{array}{c}\text { DQ874698.1 } \\
\text { AB176806.1 } \\
\text { AB176807.1 } \\
\text { NC 004530.1 } \\
\text { AB099716.1 }\end{array}$ \\
\hline
\end{tabular}

ns : no sequences 
498 Table 2: Primer and probe sequences developed in this study for quantitative real-time PCR 499 assays

\begin{tabular}{|l|l|l|c|}
\hline Target gene & \multicolumn{1}{|c|}{$\begin{array}{c}\text { Primer (F or R) and } \\
\text { TaqMan probe (P) names }\end{array}$} & Sequence (5'-3') & Size of fragments (pb) \\
\hline Cytochrome c oxidase subunit II (COII) & F_Talb_COII & 5'-CTTCCCTCCCTACGCATTCT-3' & \\
& R_Talb_COII & 5'-CACTATTCGGTGGTCTGCTTC-3' & 198 \\
& P_Talb_COII (6-FAM) & 5'-(FAM)-ACGAAATCAACGACCCCATCTAA-(BHQ1)-3' & \\
\hline NADH dehydrogenase subunit 2 (ND2) & F_Tob_ND2 & 5'-CTAGCCACCTCCTGAGCAAA-3' & 99 \\
& R_Tob_NDD2 & 5'-GCCAGGTCTTGTTTGACAGT-3' & 107 \\
& P_Tob__ND2 (6-FAM) & 5'-(FAM)-TTCTTCTGTCCCTAGGCGGTCTTCCA-(BHQ1)-3' & \\
\hline \multirow{2}{*}{ 12S ribosomal RNA (12S rRNA) } & F_Univ_12S & 5'-GACTTGGCGGTACTTTAGATCC-3' & \\
& R__Univ_12S & 5'-TGACGACGGCGGTATATAGG-3' & \\
& P_Univ_12S (6-FAM) & 5'-(FAM)-AACCGATGACCCCCGTTCAA-(BHQ1)-3' & \\
\hline
\end{tabular}




\section{For Table of Contents Only}

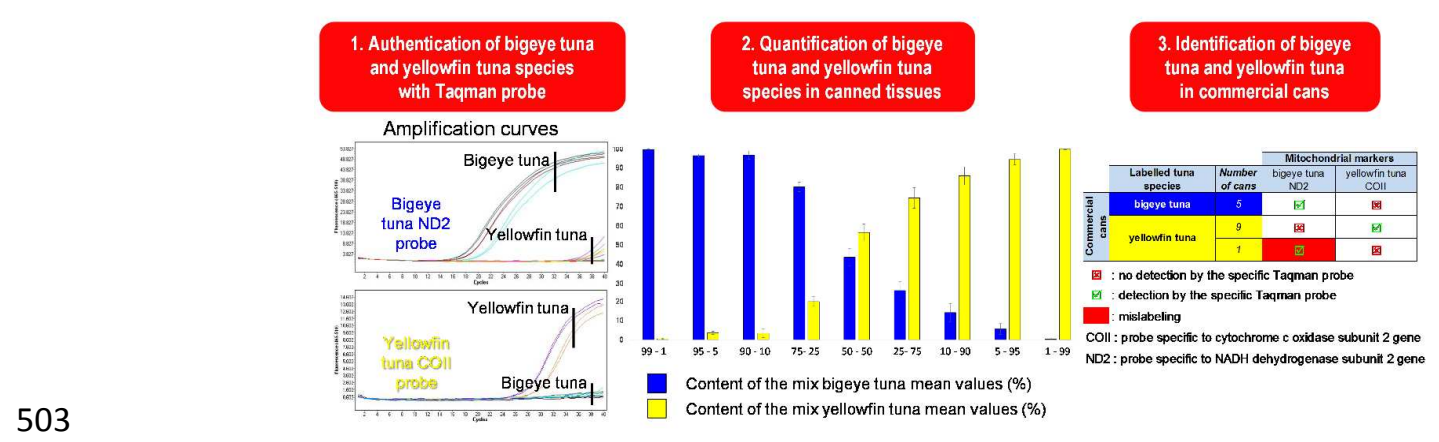

